\title{
Tärkkelysperunalajikkeen vaikutus sadon säilyvyyteen välivarastossa
}

\author{
Katja Anttila ${ }^{1)}$ \\ 1) Perunantutkimuslaitos Ruosuontie 15616900 Lammi, katja.anttila@petla.fi
}

\section{Tiivistelmä}

Perunatärkkelystehtailla on tehty huomiota siitä, että tärkkelyksen eristämisprosessissa ilmenee kausiluonteista, taloudellisesti huomattavaa hävikkiä. Hävikit ovat yleensä ajoittuneet sekä käyntikauden loppuun että kylmien sääjaksojen alkuun. Hävikkipäivinä tärkkelyssaanto on voinut olla jopa $5 \%$ alhaisempi kuin, mitä oli odotettavissa ominaispainomittauksen perusteella. Tärkkelystappioiden on oletettu liittyvän tärkkelyksen ennenaikaiseen hajoamiseen sokereiksi tai sen eristettävyyden heikkenemiseen epäonnistuneen välivarastoinnin tuloksena.

Perunantutkimuslaitoksella selvitettiin Suomen tärkkelysperunahankkeen toimesta perunan välivarastointiominaisuuksia, ja selvityksessä keskityttiin tutkimaan miten eri varastointilämpötilat ja perunoiden tuleentumisaste vaikuttavat välivarastoinnin onnistumiseen. Tässä tutkimuksessa keskityttiin puolestaan siihen, mikä on lajikevalinnan merkitys välivarastoinnin onnistumiselle.

Varastointilämpötila (Sowokinos 2001), kasvukauden olot (Sowokinos ym. 2000) sekä viljelytoimet (Madsen \& Christiansen 1996) aiheuttavat vaihtelua tärkkelyksen ominaisuuksiin, mutta myös lajikkeella on vaikutusta (Jansen ym. 2001). Alhaisissa varastolämpötiloissa perunan mukuloissa käynnistyy ns. kylmämakeutuminen eli tärkkelyksen hajoaminen sokereiksi (Sowokinos 2001). Perunalajikkeilla esiintyy suuria eroja kylmämakeutumisen kestävyydessä, mm. lastuperunalajikkeista on tutkittu paljon lajikkeiden erilaista herkkyyttä muuttaa tärkkelystä sokereiksi (Barichello ym. 1990)

Tärkkelysperunahankkeelle tehdyssä selvityksessä sekä tässä Perunantutkimuslaitoksen tutkimuksessa on huomattu, että ominaispainomittauksella määritetyn ja kemiallisesti mitatun tärkkelyspitoisuuden välinen erotus on sitä suurempi, mitä korkeampi on mukuloiden sokeripitoisuus. Tämä johtuu siitä, että ominaispainoperusteinen määritys ei pysty erottamaan sokeria ja tärkkelystä toisistaan, vaan huomioi molemmat tärkkelykseksi ja antaa näin ollen korkeasokerisille mukuloille todellista korkeampia tärkkelyspitoisuuksia.

Tärkkelysperunalajikkeista Saturna ja Kardal vaikuttavat soveltuvan hyvin aumaukseen, kun auman olosuhteet ovat hyvät. Posmon mukuloihin muodostuu enemmän sokereita, ja tärkkelyspitoisuus laskee suhteessa enemmän kuin Saturnan tai Kardalin mukuloissa. Suomen oloissa keskenkasvuiseksi jäävän Kuraksen tärkkelyspitoisuus säilyy hyvissä varastointioloissa, mutta ohuen ja keskenkasvuisen kuoren kyky suojata mukulaa painohävikiltä on heikko. Tomppa puolestaan vaikuttaa soveltuvan hyvin aumaukseen. Tomppa säilyttää hyvin todellisen tärkkelyspitoisuutensa, ja myös sokerit jäivät alhaiseksi, kun varastointiolosuhteet olivat hyvät, mutta kylmää Tomppa ei siedä. Tärkkelyslajikkeista huonoimmin välivarastoituu Seresta. Serestalla oli merkittävästi korkeammat sokeripitoisuudet mukuloissaan sekä kylmän että hyvän varastoinnin päätteeksi.

Asiasanat: tärkkelysperunalajike, välivarastointi, tärkkelys, kylmämakeutuminen 


\section{Johdanto}

Perunantutkimuslaitoksella suoritettiin vuosina 2001-2003 Suomen tärkkelysperunahankkeen toimesta selvitys tärkkelysperunan välivarastoitavuudesta. Vuonna 2004 tutkimusta jatkettiin Perunantutkimuslaitoksen toimesta. Tärkkelysperunahankkeen selvityksessä keskityttiin paljolti eri varastointilämpötilojen ja perunoiden tuleentumisasteen vaikutukseen välivarastoinnin onnistumiseen. Tässä tutkimuksessa keskityttiin puolestaan tutkimaan, että mikä vaikutus lajikkeella välivarastoinnin onnistumiselle. Tutkimushypoteesina oli, että lajike vaikuttaa välivarastoinnin onnistumiseen.

Välivarastointitutkimus nähdään tärkeäksi perunatärkkelysteollisuudessa, koska perunan korjuukausi on lyhyempi kuin tärkkelysperunatehtaiden käyntikausi ja noin puolet tehtaille tulevasta perunasta joudutaan välivarastoimaan. Vääränlaisesta välivarastoinnista aiheutuu sadolle laatu- ja määrätappioita. Tappiot ovat olleet merkittäviä lähinnä käyntikauden lopussa ja kylmien sääjaksojen alussa, jolloin tärkkelyssaanto on ollut jopa noin $5 \%$ alhaisempi kuin, mitä oli odotettavissa ominaispainomittauksen perusteella. Tärkkelystappion on oletettu liittyvän tärkkelyksen ennenaikaiseen hajoamiseen sokereiksi tai sen eristettävyyden heikkenemiseen epäonnistuneen välivarastoinnin tuloksena. Kirjallisuuden mukaan vaihtelua tärkkelyksen ominaisuuksiin aiheuttavat mm. lajikkeet (Jansen ym. 2001), varastointilämpötila (Sowokinos 2001), kasvukauden olot (Sowokinos ym. 2000) ja viljelytoimet (Madsen \& Christiansen 1996).

Perunoiden altistuminen alle +10 asteen lämpötilalle käynnistää aina tärkkelyksen hajotuksen sokereiksi. Sokereita kertyy mukuloihin sitä enemmän, mitä kylmempi varastointilämpötila on. Neljän viikon +10 asteen varastoinnin jälkeen tuleentuneiden mukuloiden sokeripitoisuudeksi mitattiin 0,5\%. Varastointi +2 asteessa tuotti mukuloihin puolestaan yli $3 \%$ sokeripitoisuuden (Burton 1965). Kylmässä varastotilassa mukuloissa alkavat toimia hydrolyyttiset, tärkkelystä hajottavat entsyymit, ja tärkkelystä aletaan hajottaa sokereiksi, ja tästä on seurauksena mukuloiden kylmämakeutuminen (Cottrell ym. 1993, Sowokinos 2001)

Lajikkeiden välisellä ja lajikkeen sisäisellä vaihtelulla mukuloiden koossa on merkitystä eroihin tärkkelyspitoisuuksissa ja sen eristettävyydessä, sillä mukulakoon kasvaessa tärkkelysjyvästen koon on havaittu kasvavan (Christersen \& Madsen 1996). Tämä on merkityksellistä, koska pienijyväisen tärkkelyksen on huomattu hajoavan entsymaattisen toiminnan ansiosta helpommin kuin suurijyväisen tärkkelyksen. (Barichello ym. 1990, Cottrell ym. 1993). Eri lajikkeilla on myös erilainen herkkyys muuntaa tärkkelystä sokereiksi. Tätä ominaisuutta on tutkittu paljon mm. perunalastulajikkeista (Barichello ym. 1990). Eräänä selittävänä tekijänä lajike-eroihin on pidetty tärkkelysjyvästen kiderakenteen järjestäytyneisyyden astetta. Lajikkeet, joilla on järjestynyt kiderakenne, kestävät paremmin kylmiä varastointioloja makeutumatta kuin lajikkeet, joilla on huonosti järjestäytynyt kiderakenne (Barichello ym. 1990).

Tärkkelyksen hajoamisen lisäksi perunoissa voi tapahtua painohävikkiä. Perunan koostumuksesta noin $77 \%$ on vettä, ja vesi voi poistua mukuloista joko haihtumalla suoraan pinnan läpi tai hengityksen yhteydessä. Sekä haihtumista että hengitystä lisäävät samat tekijät, joita ovat mm. mukuloiden pintavauriot, varastotilan alhainen ilmankosteus ja mukuloiden keskenkasvuisuus (van Es \& Hartmans, 1987ab). Lisäksi hengitys nopeutuu voimakkaasti kun lämpötila varastossa laskee alle +4 asteen (van Es \& Hartmans, 1987a).

\section{Aineisto ja menetelmät}

Tutkimuksessa oli mukana kuusi tärkkelysperunalajiketta, Saturna, Kardal, Kuras, Tomppa, Posmo ja Seresta. Saturna ja Tomppa ovat melko aikaisia lajikkeita, joiden tärkkelyspitoisuus asettuu yleensä välille 17 - 19 \% (Kangas ym. 2004). Posmo ja Seresta ovat melko myöhäisiä ja hyvin korkean tärkkelyspitoisuuden omaavia. Kardal ja Kuras ovat hyvin myöhäisiä, korkean satotason omaavia lajikkeita, joiden kasvu keskeytyy yleensä ensimmäisiin hallaöihin (Kangas ym. 2004).

Saturnan, Kardalin, Kuraksen, Tompan ja Posmon tutkimusnäytteet kerättiin tärkkelysperunan Lammin lajikekokeesta ja Serestan näytteet Perunantutkimuslaitoksella sijainneesta talousviljelmästä. Kaikista lajikkeista koottiin noin $400 \mathrm{~kg}: \mathrm{n}$ erä perunaa, josta erotettiin lajikkeittain kolme toistoa kutakin käsittelyä kohden. Kaikilla lajikkeilla oli neljä käsittelyä; nosto, kylmäkäsittely, tasalämpöinen varastointi 
ja aumaus. Aumausnäytteet olivat kooltaan $10 \mathrm{~kg}$ ja muut $5 \mathrm{~kg}$. Kaikista lajikkeista määritettiin noston ja käsittelyjen jälkeen sokeri- ja kuiva-ainepitoisuus sekä ominaispainoon perustava ja kemiallinen, todellinen tärkkelyspitoisuus (Megazyme). Lisäksi kaikista lajikkeista määritettiin käsittelyjen jälkeen painohävikit.

Alhaisen lämpötilan vaikutusta tutkittiin kylmäkäsittelyn avulla, jossa perunat altistettiin viikoksi +0 asteeseen ja kahdeksi vuorokaudeksi +8 asteen lämpötilalle. Tasalämpöinen varastointi hyvissä oloissa tapahtui +8 asteisessa varastokaapissa kuuden viikon ajan. Aumaus tapahtui kuuden viikon ajan todellisessa, viljelmämitassa tuotetusta Posmosta perustetussa, tärkkelysperuna-aumassa.

Aumaan ja kaappeihin sijoitettiin olosuhdekeräimiä (HOBO Pro RH/Temp), jotka tallensivat puolen tunnin välein koko varastointiajan lämpötilan $\left({ }^{\circ} \mathrm{C}\right)$, kastepisteen $\left({ }^{\circ} \mathrm{C}\right)$ sekä ilman kokonaisvesipitoisuuden $\left(\mathrm{g} / \mathrm{m}^{3}\right)$ ja suhteellisen kosteuden $(\mathrm{RH}-\%)$. Ulkoilman sääoloja seurattiin
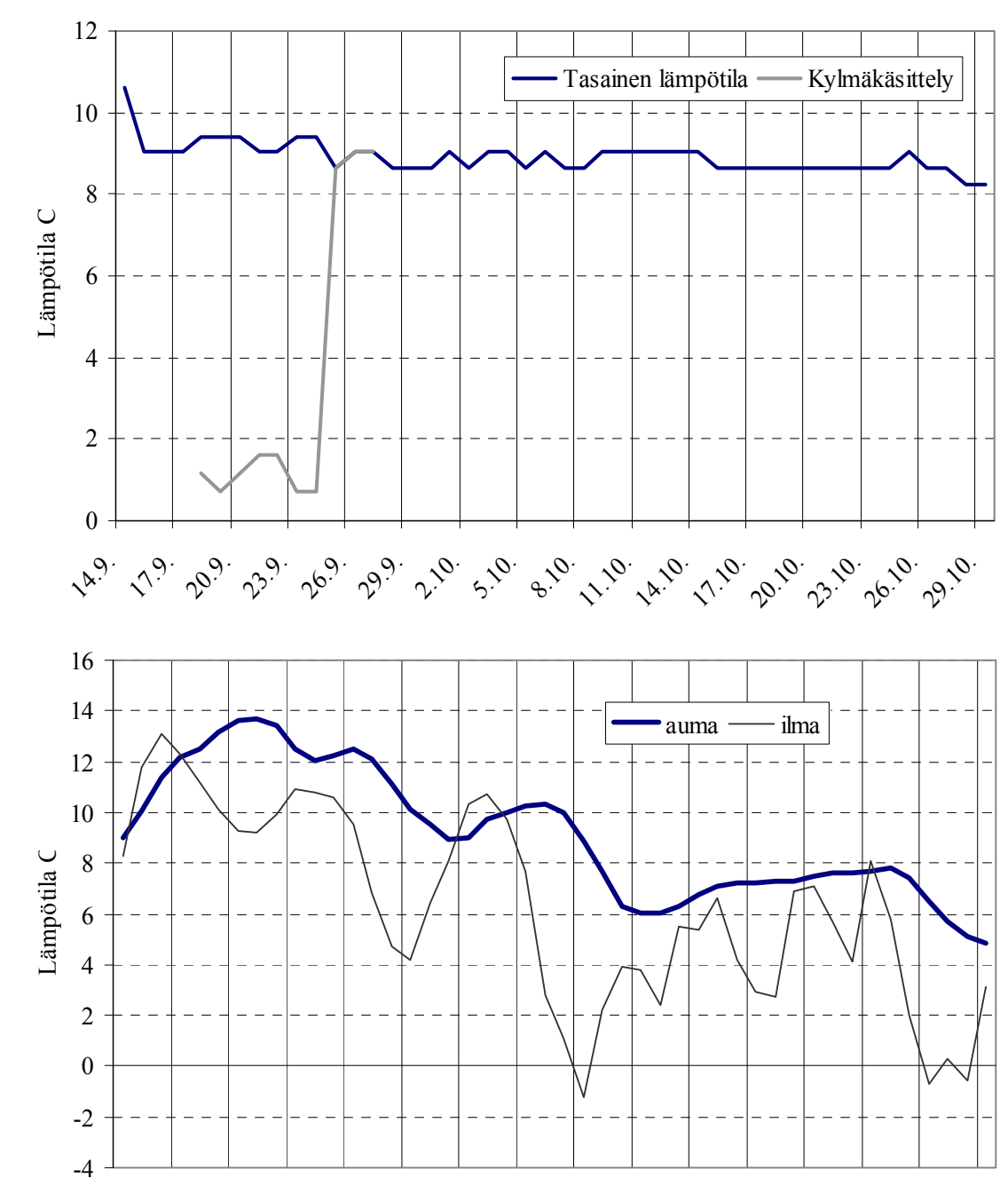

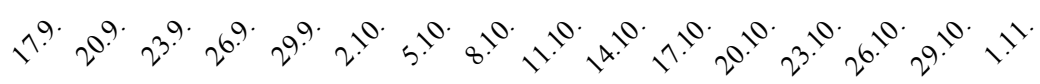

Kuva 1. Auma- ja ulkolämpötilan sekä kaappien lämpötilan kehitys Perunantutkimuslaitoksella 2004 automaattisääasemalla (Hardi Metropole). Auman, ulkolämpötilan ja kaappien lämpötilakehitys ilmenee kuvasta 1.

+8 astetta on kirjallisuuden mukaan optimi-lämpötila tärkkelyksen säilymiselle (van Es \& Hartmans 1987c). Aumassa lämpötilaolot olivat myös hyvät koko aumausajan. Lämpötila laski maltillisesti, ja alhaisinkin mitattu lämpötila oli yli + 4 astetta.

\section{Määritykset}

Ominaispainoon perustuvan tärkkelys- ja

kuiva-ainepitoisuuden määrittämisessä noin $5 \mathrm{~kg}$ perunanäytettä punnittiin sekä ilmassa että vedessä, ja näiden avulla laskettiin näytteen ominaispaino. Ominaispainon avulla saatiin tärkkelyspitoisuus kaavasta: Tärkkelys- $\%=$ 214.53 x ominaispaino 217.76 (Järvi ym. 1998).

Kuiva-ainepitoisuus laskettiin ominaispainon avulla kaavasta: Kuivaaine- $\%=24.182+211.04$

x (ominaispaino - 1.0988) (van Es \& Hartmans, 1987c).

Ominaispaino-määrityksen jälkeen jokaisesta näytteestä otettiin 10 mukulaa. Puolet mukuloista hienonnettiin (Workmatic 6, Malavasi, Crower, Australia), ja hienonnettu materiaali laitettiin 
petrimaljoille, pakastettiin ja kylmäkuivattiin (Vacuubrand ALPHA 1-2 LD, Wertheim, Germany). Toinen puoli mukuloista hienonnettiin sokerimäärityksiä varten.

Mukuloiden sisältämä glukoosin, fruktoosin ja sakkaroosin pitoisuus määritettiin BoehringenMannheimin valmista kittiä käyttäen (UV method for the determination of sucrose, D-glucose and Dfructose in foodstuffs and other materials Cat. No. 716 260, Boehringen-Mannheim). Hienonnettu näyte $(50 \mathrm{~g})$ ja vesi $(150 \mathrm{ml})$ homogenisoitiin ja näytteeseen lisättiin Carrez I-, Carrez I- ja NaOH-liuosta sekä n-oktanolia. Näyte laimennettiin 500 ml:ksi. Näytteen absorbanssi luettiin 15 minuutin kuluttua reaktion alkamisesta $340 \mathrm{~nm}$ aallonpituudella.

Tärkkelyspitoisuus määritettiin kylmäkuivatusta materiaalista käyttäen Megazyme-kittiä (Megazyme total starch assay kit, Megazyme International Ireland Ltd. ICC Standard method No. 168). 50-100 mg:aan kylmäkuivattua ja jauhettua perunamateriaalia lisättiin etanolia ja inkuboitiin 5 min lämpötilassa $80-85^{\circ} \mathrm{C}$. Inkuboinnin jälkeen näytteeseen lisättiin etanolia, ja näyte sentrifugoitiin. Tämän jälkeen etanolilisäys ja sentrifugointi toistettiin. Uuton jälkeen pelletin sekaan lisättiin $3 \mathrm{ml} \alpha$-amylaasia, ja näytettä inkuboitiin kiehuvassa vedessä 6 minuuttia. Näytteeseen lisättiin 4 ml natriumasetaattipuskuria ja $0,1 \mathrm{ml}$ amyloglukosidaasia ja inkuboitiin 50 asteisessa vesihauteesssa 30 minuuttia. Näytteestä otettiin osanäyte, joka laimennettiin tislatulla vedellä ja sentrifugoitiin. Tämän jälkeen näytteeseen lisättiin $3 \mathrm{ml}$ GOPOD -reagenssia ja inkuboitiin 50 asteessa 20 minuuttia. Absorbanssit mitattiin $510 \mathrm{~nm}$ aallonpituudella.

Painohävikki määritettiin punnitsemalla säkit heti käsittelyjen jälkeen ja vertaamalla painoja ennen käsittelyä punnittuihin painoihin.

Aineiston tilastollinen tarkastelu suoritettiin SPSS 12.0 avulla (SPSS Inc., Chicago, USA) käyttäen varianssi-analyysiä, korrelaatiota ja Tukeyn testiä. Kaikki tuloksissa mainitut merkitsevät erot ovat merkitseviä, kun $\mathrm{p}<0,05$.

\section{Tulokset ja tulosten tarkastelu}

\section{Ominaispainon, sokeripitoisuuden sekä todellisen tärkkelyspitoisuuden välinen yhteys}

Tärkkelysperunahankkeelle tehdyssä selvityksessä huomattiin, että sokeripitoisuus korreloi hyvin ominaispainomittauksella saadun tärkkelyspitoisuuden ja kemiallisesti määritetyn todellisen tärkkelyspitoisuuden erotuksen kanssa (Anttila ym. 2003). Tämä sama näkyi trendinomaisesti myös vuoden 2004 tuloksissa niin, että ominaispainoperusteisen ja kemiallisen tärkkelysmäärityksen välinen

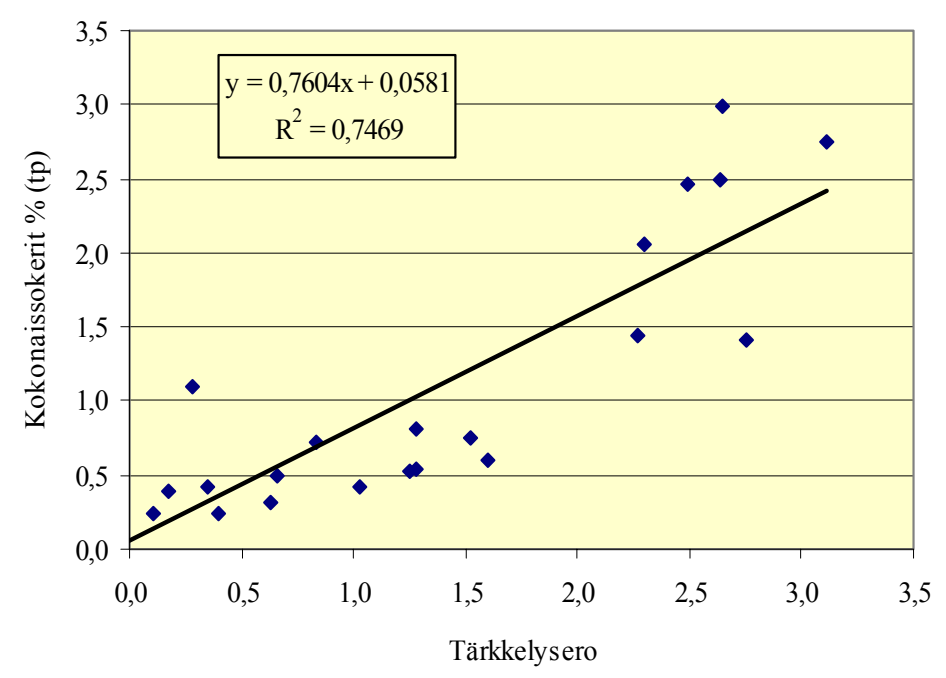

Kuva 2. Kokonaissokeripitoisuuden riippuvuus ominaispainoperusteisen ja todellisen tärkkelyspitoisuuden ero selittää tuorepainoa kohti laskettua sokeripitoisuutta selitysasteella 0,75 (kuva 2). Ominaispainoperusteinen tärkkelysmääritys perustuu mukulan kuiva-ainepitoisuuteen, josta suurin osa on tärkkelystä. Ominaispainon avulla voidaan laskea mukuloiden tärkkelyspitoisuus tarkasti, kun kuivaaineen sokeripitoisuus on alhainen (van Es \& Hartmans, 1987d). Mittaustapa ei kuitenkaan pysty erottamaan kuiva-aineen koostumusta, jolloin ominaispainoon perustavassa määritys antaa korkean sokeripitoisuuden omaaville mukuloille todellista korkeamman tärkkelyspitoisuuden. Tämä selittää sen, miksi tärkkelysperunatehtailla on saatu kylmien sääjaksojen jälkeen pienempiä tärkkelyssaantoja kuin 
ominaispainomittauksen jälkeen oli odotettavissa.

\section{Todellinen tärkkelyspitoisuus}

Mikään nyt testatuista lajikkeista ei siedä varastointia kylmässä, vaan kylmissä oloissa kaikkien lajikkeiden tärkkelyspitoisuus laskee ja sokeripitoisuus nousee merkittävästi. Osalla lajikkeista tapahtui kuitenkin myös hyvissä oloissa tärkkelyspitoisuuden laskemista ja sokeripitoisuuden nousemista.

Kuvassa 3 on kaikkien lajikkeiden todelliset, kemiallisesti määritetyt tärkkelyspitoisuudet noston ja käsittelyiden jälkeen. Noston jälkeen mitattu tärkkelyspitoisuus oli matalin Tompalla (17,9\%) ja korkein Posmolla $(20,8 \%)$. Nostotilanteeseen verrattuna kylmäkäsittely laski merkittävästi kaikkien lajikkeiden

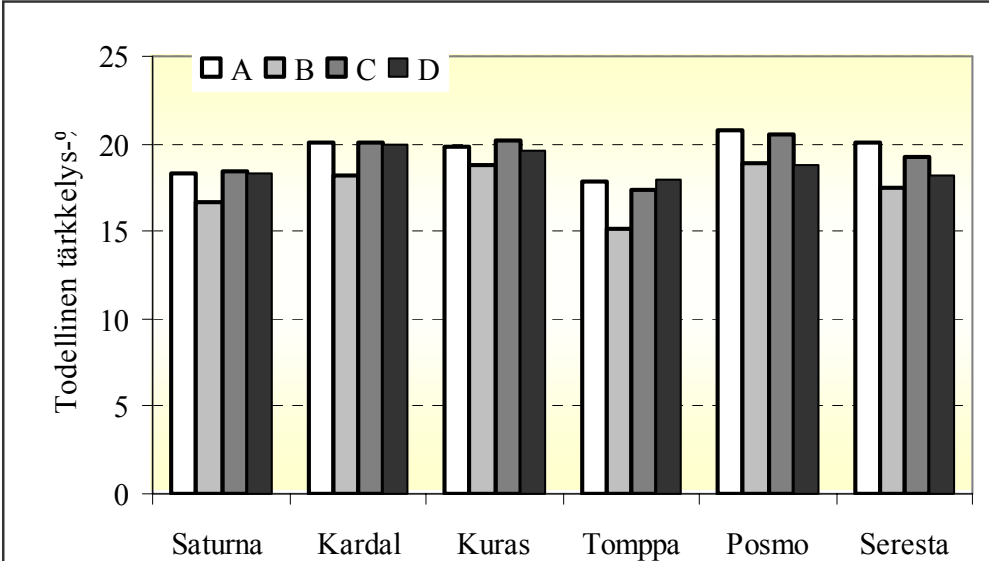

A. nosto; B. 1 vk $0{ }^{\circ} \mathrm{C}, 2$ vrk $8{ }^{\circ} \mathrm{C} ;$ C. $8{ }^{\circ} \mathrm{C} 6$ vk; D. auma 6 vk Kuva 3. Todelliset tärkkelyspitoisuudet noston ja käsittelyiden jälkeen

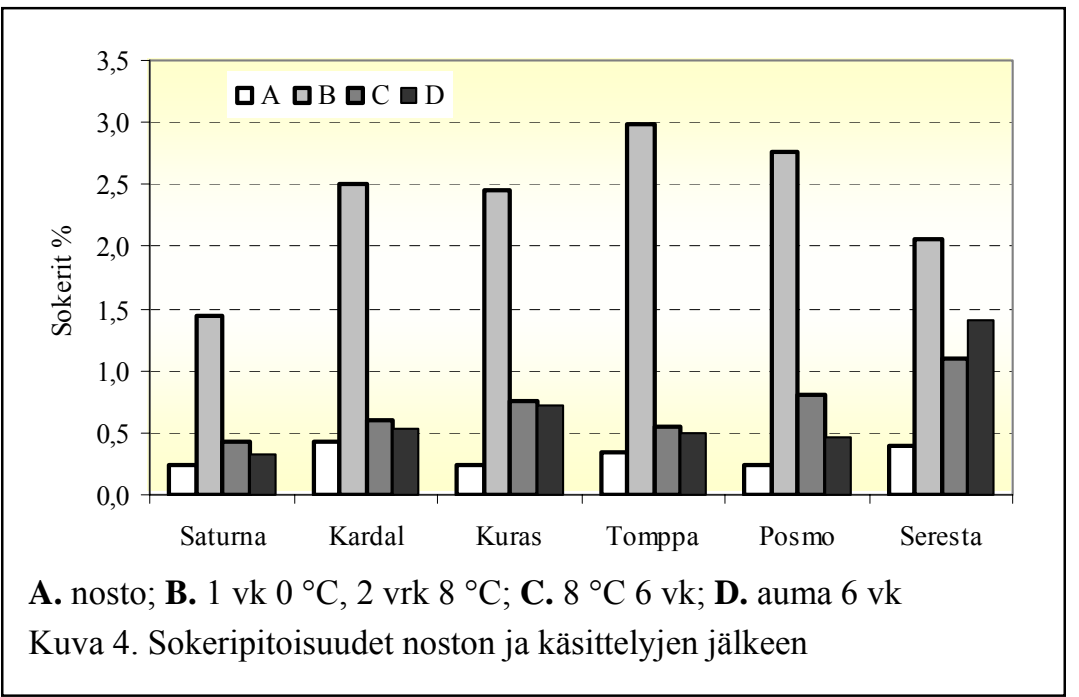
tärkkelyspitoisuutta. Aumausajan pituinen tasalämpöinen varastointi +8 asteessa ei puolestaan laskenut merkittävästi yhdenkään lajikkeen tärkkelyspitoisuutta nostotilanteeseen verrattuna. Aumavälivarastoinnin aikana Saturnan, Kardalin, Kuraksen ja Tompan tärkkelyspitoisuudet säilyivät samalla tasolla, kuin mitä ne olivat nostossa. Sen sijaan Posmon tärkkelyspitoisuus laski 2,1 prosenttiyksikköä ja Serestan 1,9 prosenttiyksikköä nostotilanteeseen verrattuna ja erot olivat merkitseviä.

\section{Sokerit}

Kaikilla lajikkeilla oli matalat sokeripitoisuudet heti noston jälkeen, jolloin ne vaihtelivat välillä $0,2-0,5 \%$. Kylmäaltistus nosti merkittävästi kaikkien lajikkeiden sokeripitoisuuksia ja korkeimmat pitoisuudet mitattiin Tompan $(2,98 \%)$ ja Posmon $(2,75 \%)$ mukuloista. Kylmäaltistuksen jälkeen alhaisin sokeripitoisuus oli Saturnalla (1,44\%). Nostossa olleisiin sokeripitoisuuksiin verrattuna kuuden viikon varastointi +8 asteessa nosti merkittävästi Kuraksen ja Serestan sokeripitoisuuksia. Aumaus nosti merkittävästi nostoon verrattuna ainoastaan Serestan sokeripitoisuutta (Kuva 4). Sokeripitoisuudet kohosivat auman ja tasalämpöisen kaapin hyvissä varastointioloissa myöhäisillä lajikkeilla Kuraksella ja Serestella. Makeutumisen on todettu olevan suurempi ongelma keskenkasvuisilla mukuloilla kuin tuleentuneilla (Davies \& Viola 1992). Lisäksi Posmon ja Serestan mukulat olivat selvästi mustelmoituneita ja käsittelystressin on huomattu lisäävän sokerin muodostumista mukuloissa (Sowokinos ym. 1987).

\section{Kuiva-aine ja painohävikki}




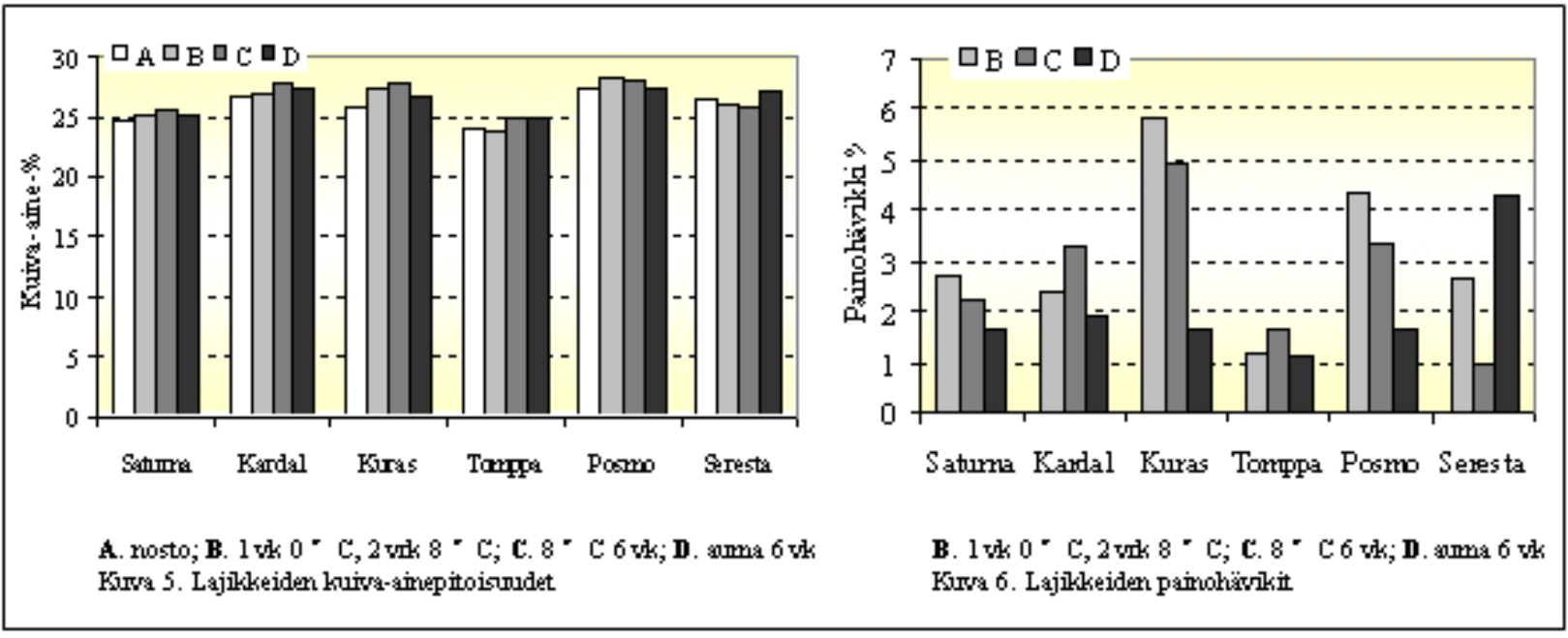

Heti noston jälkeen määritetty kuiva-ainepitoisuus oli pienin Tompalla ja Saturnalla sekä korkein Posmolla. Kylmäaltistuksessa Tompan ja Serestan kuiva-ainepitoisuudet laskivat ja muilla lajikkeilla kohosivat nostotilanteeseen verrattuna. Ero oli merkitsevä Saturnalla, Kuraksella ja Posmolla. Tasalämpöinen varastointi +8 asteessa nosti merkittävästi nostoon verrattuna kaikkien muiden paitsi Serestan kuiva-ainepitoisuutta. Aumauksen aikana kaikkien muiden kuiva-ainepitoisuudet nousivat paitsi Posmon, jonka kuiva-ainepitoisuus oli aumauksen jälkeen sama kuin nostossa, ja erot olivat merkitseviä muilla paitsi Posmolla ja Serestalla (kuva 5).

Kylmäkäsittelyn jälkeen suurimmat painohävikit mitattiin Saturnasta, Kuraksesta ja Posmosta. Tasalämpöinen varastointi puolestaan aiheutti suurimman painohävikin Kardalille ja Tompalle. Serestassa oli ainoana lajikkeena suurin painohävikki aumauksen päätteeksi (Kuva 6).

Mukuloista poistuu vettä hengityksen lisäksi suoraan pinnan läpi haihtumalla (Rastovski 1987). Painohävikkitulosten perusteella kaikilla lajikkeilla laskettiin laskennallinen kuiva-ainepitoisuus sen oletuksen pohjalta, että painohävikki olisi ollut suurimmaksi osaksi veden haihtumista, ja hengityksessä ei olisi kulutettu tärkkelystä. Tämän jälkeen laskennallista kuiva-ainepitoisuutta verrattiin todelliseen kuivaainepitoisuuteen. Jos painohävikki oli ollut suurimmaksi osaksi veden haihtumista, niin todellinen ja laskennallinen kuiva-ainepitoisuus olivat suurin piirtein samat tai todellinen pitoisuus oli laskennallista korkeampi. Jos laskennallinen pitoisuus oli puolestaan korkeampi kuin todellinen, eli erotus oli negatiivinen, niin tällöin oletuksen oli, että kuiva-aineen tärkkelystä oli hajotettu ja käytetty energianlähteenä hengityksessä. (van Es \& Hartmans 1987ab).

Kuvasta 7 näkyy, että tämän laskelman mukaan kylmäkäsittelyn aikana kaikki lajikkeet olisivat

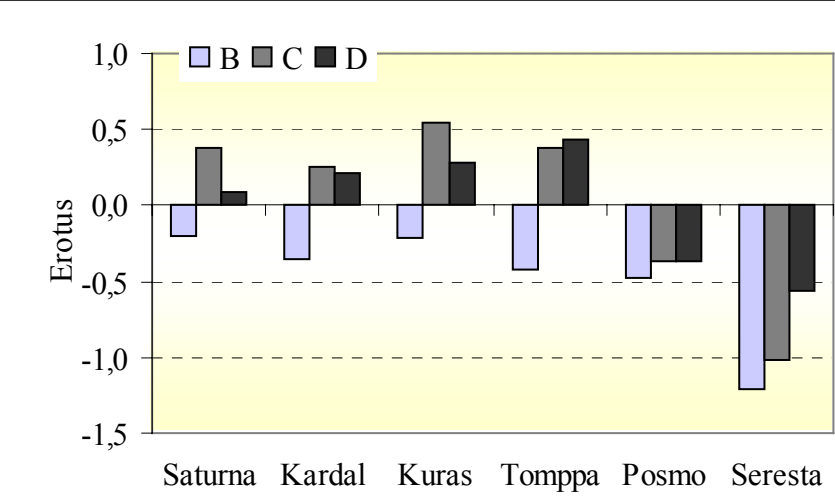

B. 1 vk $0{ }^{\circ} \mathrm{C}, 2$ vrk $8^{\circ} \mathrm{C} ;$ C. $8{ }^{\circ} \mathrm{C} 6$ vk; D. auma 6 vk Kuva 7. Laskennallisen ja todellisen kuiva-ainepitoisuuden erotus käyttäneet tärkkelystä hengityksen ylläpitoon.

Sen sijaan hyvissä varastointioloissa hengitys olisi ollut hitaampaa ja vettä olisi poistunut pääasiassa pinnan läpi haihtumalla kaikilla muilla lajikkeilla paitsi Posmolla ja Serestalla. Molempien mukulat olivat selvästi mustelmoituneita ja lisäksi Posmon mukuloista vajaa $40 \%$ oli ruven peittämiä (ulkoisen laadun tuloksia ei esitetty). Mukuloiden ulkoisen laadun vikojen on todettu lisäävän painohävikkiä (Meijers 1987).

\section{Johtopäätökset}

Yhteenvetona voidaan sanoa, että millekään lajikkeelle ei voida suositella varastointia 
kylmässä, koska kaikkien lajikkeiden sokeripitoisuudet kohosivat merkittävästi ja samalla tärkkelyspitoisuudet laskivat. On siis todella tärkeää, että tärkkelysperuna-auman lämpötila ei pääse laskemaan liian alas. Hyvin hoidetussa aumassa Saturnan, Kardalin, Kuraksen ja Tompan tärkkelyspitoisuus säilyi hyvänä ja sokeripitoisuudet olivat alhaisia. Tämän lisäksi näiden lajikkeiden painohävikit jäivät pieniksi todellisessa tärkkelysperuna-aumassa. Tätä nelikkoa voi suositelle käytettäväksi välivarastoitavan tärkkelysperunan viljelyyn. Sen sijaan Posmolla ja Serestalla tärkkelyksen hajottamista vaikuttaisi tapahtuvan myös hyvissä varastointioloissa. Posmon kohdalla tärkkelysperunahankkeen selvityksessä ilmi tulleet arvelut välivarastointiin sopimattomuudesta saivat täten vahvistusta (Mäkelä ym. 2002, Anttila ym. 2003).

\section{Kirjallisuus}

Anttila, K., Mäkelä, P., Ali-Kippari, R., Myyryläinen, T. ja Kuisma, P. 2003. Tärkkelysperunahankeen raportti vuodelta 2003. http://www.tarkkelysperuna.info/evi_images/VxlivarastointiosioxRaporttux2003.doc 21.11.2005.

Barichello, V., Yada, R.Y., Coffin, R.H. \& Stanley, D.W. 1990. Low temperature sweetening in susceptible and resistant potatoes: starch structure and composition. Journal of Food Science 55: 1054-1059.

Burton, W.G. 1965. Some observations on the growth substances in either extracts of the potato tuber, Physiologia 9: $567-587$.

Cottrell, J.E., Duffus, C.M., Paterson, L., MacKay, G.R. \& Allison, M.J. 1993. Changes in surface morphology of starch granules of the cultivated potato, Solanum tuberosum L, during storage. Potato Research 36: $119-125$.

Davies, H.V. \& Viola, R. 1992. Regulation of sugar accumalation in stored potato tubers. Postharvest News and Information 3: 97-100.

Jansen, G., Flamme, W.I., Schyler, K. \& Vandrey, M. 2001. Tuber and starch quality of wild and cultivated potato species and cultivars. Potato Research 44: 137-146.

Järvi, A., Kangas, A., Mattila, I., Mäkelä, L., Rahkonen, A., Salo, Y., Vuorinen, M. \& Öfversten, J. 1998. Virallisten lajikekokeiden suoritusohjeet. Maatalouden tutkimuskeskuksen julkaisuja, sarja B 14. $71 \mathrm{~s}$.

Kangas, A., Laine, A., Niskanen, M., Salo, Y., Vuorinen, M., Jauhiainen, L. ja Nikander, H. 2004. Virallisten lajikekokeiden tulokset 1997-2004. MTT:n selvityksiä 83. 192 s.

Madsen, M.H. \& Christiansen, J. 1996. Potato Starch - possibility to influence starch quality. In Abstracts of Conference papers, posters and demonstrations of the $13^{\text {th }}$ Trennal Conference of the EAPR, Veldhoven 14-19 July 1996. Ss. 617-618.

Meijers, C.P. 1987. Diseases and defects liable to affect during storage. Teoksessa Rastovski, A., van Es, A. Storage of potatoes, post-harvest behaviour, store design, storage practice, handling, s.138-166.

Mäkelä, P., Kuisma, P., Ali-Kippari, R. ja Myyryläinen, T. 2002. Tärkkelysperunahankkeen väliraportti. http://www.tarkkelysperuna.info/evi_images/Loppuraporttixliitteetb.docT s.48-66. 21.11.2005

Rastovski, A. 1987. Storage losses. Teoksessa Rastovski, A., van Es, A. Storage of potatoes, post-harvest behaviour, store design, storage practice, handling, s. 169-173.

Sowokinos, J.R., Orr, P.H., Knper, J.A. \& Varns, J.L. 1987. Influence of potato storage and handling stresss on sugars, chip quality and integrity of the starch (amyloplast) membrane. American potato Journal 64: $213-226$.

Sowokinos, J.R. Chock, C.C., Stieber, T.D. \& Eldredge, E.P. 2000. Compositional and enzymatic changes associated with the sugar-end defect in Russet Burbank potatoes. American Journal of Potato Research 77, 47-56.

Sowokinos, J.R. 2001. Biochemial and molecular control of cold-induced sweetening in potatoes. Invited review. American Journal of Potato Research 78: 221-236.

van Es, A. \& Hartmans, K.J. 1987a. 1987. Respiration. Teoksessa Rastovski, A., Es, A. van. Storage of potatoes, post-harvest behaviour, store design, storage practice, handling, s. 120-128.

van Es, A. \& Hartmans, K.J. 1987b. 1987. Water balance of the potato tuber. Teoksessa Rastovski, A., van Es, A. Storage of potatoes, post-harvest behaviour, store design, storage practice, handling, s. 129-137.

van Es, A. \& Hartmans, K.J. 1987c. Sugars and starch during tuberization, storage and sprouting. Teoksessa Teoksessa Rastovski, A., van Es, A. Storage of potatoes, post-harvest behaviour, store design, storage practice, handling, s. 82-98.

van Es, A. \& Hartmans, K.J. 1987d. Structure and chemical composition of the potato. Teoksessa Rastovski, A., van Es, A. Storage of potatoes, post-harvest behaviour, store design, storage practice, handling, s. 17-81. 